\title{
NASKAH PERUKUNAN BATU CANGKU: PERAN DAKWAH TUAN GURU TERHADAP PERKEMBANGAN BUDAYA LITERASI MASYARAKAT MUSLIM-SASAK
}

\author{
Yusri Hamzani \\ Email: yusri231192@gmail.com \\ Alumni Prodi Aqidah dan Filsafat Islam, Fakultas Ushuluddin dan \\ Pemikiran Islam, UIN Sunan Kalijaga, Yogyakarta
}

\begin{abstract}
This paper discusses the diversity of Sasak villagers at Batu Cangku, Sapit village, Suela subdistrict, East Lombok, West Nusa Tenggara in the past. This paper concerns on three major issues; (1) The history of the diversity of Sasak villagers in the past, (2) The role of Islamic teachers to transform the diversity, (3) The first Mazhab adopted by the villagers after the transformation from Islam Wetu Telu to Islam Waktu Lima. These issues were analyzed with min al$n \bar{a}$ s ilā al-wāqi'. Regarding to the history of the diversity of Sasak villagers, the present researcher found that the transformation occured in their faith;started from Animism-Dinamism, HinduBuddha, Boda Sasak-Islam. In applying Islamic thought, they were divided into two different communities; Islam Wetu Telu and Islam Waktu Lima. The first community was closer to Islam Abangan in Java, while the second community was the same as Islam as general. In addition, in relation to Islamic teachers, they were as the agents of change of this transformation. Meanwhile, in term of the thought adopted, the majority of Islamic teachers taught Mazhab Syāfi'i. As a result, The villagers, the first generation of Islam Waktu Lima, practiced this Mazhab for their worship. The data were found in a manuscript of Islam Waktu Lima as their guidance for daily worship.
\end{abstract}

Keywords: Religious Style, Telu Time Islam, Five Times Islam, Master Teacher. 


\begin{abstract}
Abstrak
Artikel ini berbicara tentang realitas keberagamaan masa lalu masyarakat Batu Cangku, Desa Sapit, Kecamatan Suela, Lombok Timur, NTB. Ada tiga hal utama yang dikaji dalam artikel ini: (1) Sejarah keberagamaan masyarakat Sasak pada masa lalu. (2) Peran dakwah Tuan Guru dalam transformasi corak keberagamaan dan tradisi literasi masyarakat Batu Cangku. (3) Mazhab fikih yang pertama kali dianut oleh masyarakat Sasak pasca perubahan dari Islam Waktu Telu menuju Islam Waktu Lima. Tiga aspek ini dikaji dengan menggunakan metode min al-nāṣ ilä al-wāqi'. Dari sisi sejarah keberagamaan masyarakat Sasak, penulis menemukan bahwa telah terjadi tranformasi bentuk kepercayaan: mulai dari Animisme-Dinamisme, Hindu-Budha, Boda-Sasak dan Islam. Dalam menghayati Agama Islam, mereka terpecah menjadi dua kelompok besar, kelompok Islam Waktu Telu dan Islam Waktu Lima. Kelompok pertama tidak jauh berbeda dengan kelompok Islam Abangan di Jawa, sedangkan kelompok kedua tidak jauh berbeda dengan masyarakat Muslim saat ini. Dari aspek dakwah Tuan Guru, kita dapat melihat bahwa mereka merupakan aktor perubahan corak keberagamaan masyarakat Sasak. Sedangkan dari aspek mazhab yang mereka anut, mayoritas Tuan Guru yang berdakwah menganut mazhab Syāfi’i sehingga masyarakat Islam Waktu Lima generasi pertama juga menggunakan mazhab yang sama dalam ritual peribadatannya. Realitas itu dikonfirmasi oleh manuskrip Perukunan yang masih disimpan di Dusun Batu Cangku.
\end{abstract}

Kata Kunci: Corak Keberagamaan, Islam Waktu Telu, Islam Waktu Lima, Tuan Guru. 


\section{A. Pendahuluan}

Manuskrip merupakan naskah kuno yang menghubungkan masa lalu dengan masa sekarang. Secara fungsional, naskah kuno tidak jauh berbeda dengan bangunan masa lalu seperti candi atau bangunanbangunan bersejarah yang lain: sama-sama mendiktekan ulang realitas masa lampau dengan alur yang mirip. Perbedaanya hanya dalam media penyampaian, naskah kuno menggunakan media aksara dan bahasa, sedangkan candi dan bangunankuno menggunakan media struktur bangunan atau relief yang dipahat rapi di pinggir bangunan.

Indonesia merupakan salah satu negara yang kaya akan naskah kuno. Saking banyaknya naskah yang dimiliki oleh bangsa ini, sampai saat ini, belum dijumpai katalog utuh yang menyajikan referensi komprehensif tentang manuskrip. Beberapa buku yang sering digunakan sebagai katalog adalah A Catalogue of Catalogues of Javanese MSS yang diterbitkan pada tahun 1984, Catalogues Des Catalogues de Manuscrits Malais yang diterbitkan pada tahun 1980, Khazanah Naskah: Panduan Koleksi Naskah Indonesia Se-Dunia yang ditulis oleh Henri Chambert-Loir dan Oman Fathurrahman pada tahun 1999 dan
Indonesian Manuscripts from the Island of Java, Madura, Bali and Lombok yang ditulis oleh Dick van der Meij pada tahun 2017.

Dalam katalog-katalog tersebut, mereka menyebutkan ratusan sampai puluhan ribu naskah kuno yang tersebar di seantero jagat Nusantara termasuk Indonesia. Walaupun demikian, tulisan tersebut bagaikan sebuah bangunan yang saling melengkapi satu dengan yang lain. Untuk mendapatkan katalog yang komprehensif, maka kita harus melihat seluruh tulisan tersebut. Namun di sisi lain, polemik jumlah naskah Nusantara juga masih terus terjadi. Ismail Husen pernah mengemukakan angka 5.000 untuk jumlah naskah Nusantara. Namun Chambert-Loir mengemukakan 4.000 naskah, begitu juga dengan Russel Jones yang menyebutkan angka 10.000. Kuantitas ini merujuk kepada naskah yang tersebar di dalam negeri. Sedangkan naskah Nusantara yang tersebar di luar negeri diklaim lebih banyak lagi jumlahnya. ${ }^{1}$

1 Lihat Faizal Amin, "Preservasi Naskah Klasik" dalam Jurnal Khatulistiwa, (Vol. 1, No. 1, Maret 2011), 90. Lihat juga Oman Fathurrahman, "Proyek Digitalisasi Naskah Aceh dan Dampaknya bagi Pengembangan Perpustakaan Digital Naskah Nusantara" dalam Makalahyang Disampaikan dalam Seminar Internasional Kebijakan dan Strategi 
Sri Wulan Rujiati Muyadi, berdasarkan penelitian ChambertLior, Miller dan Ibrahim bin Ismail, mencatat jumlah naskah Melayu yang tersebar di 29 negara, yaitu Afrika Selatan, Amerika, Australia, Austria, Belanda, Belgia, Brunei, Ceko-Slowakia, Denmark, Hongaria, India, Indonesia, Inggris, Irlandia, Italia, Jerman Barat, Jerman Timur, Malaysia, Mesir, Norwegia, Polandia, Perancis, Rusia, Singapura, Spanyol, Srilangka, Swedia, Swiss dan Thailand. Jumlah negara ini berkurang satu, karena Jerman Timur dan Barat telah menjadi. Naskah yang tersebar di beberapa negara itu tidak termasuk naskah yang ditulis dalam bahasa-bahasa sukuan yang majemuk di Nusantara, sebab naskah berbahasa Jawa saja dikatakan lebih dari 19.000 naskah. ${ }^{2}$ Selain itu, naskah-naskah Nusantara juga tersimpan di beberapa perpustakaan, seperti British Library of Congress, Perpustakaan Nasional, Jakarta, Pusat Dokumentasi Riau, Arkib Brunei Darussalam, dan Pusat Kebangsaan Manuskrip Melayu yang

Pelestarian Naskah Kuno Aceh di Museum Negeri Aceh pada tanggal 22-23 Desember 2009.

2 Nindya Noegraha, "Tradisi Penulisan Naskah Jawa" pada Seminar Antarbangsa Manuskrip Melayu, di (Kuala Lumpur, 3-4 Oktober, 1995), 2. telah berhasil mengumpulkan 2.100 naskah.

Dari sisi historis, penyebaran naskah-naskah ini disebabkan oleh kolonialisasiyangberlangsung cukup lama di Bumi Pertiwi. Para kolonialis tidak hanya "menjarah" sumber daya alam yang dimiliki bangsa ini, namun mereka juga menjarah khazanah manuskrip Nusantara yang tak terhingga jumlahnya. Terlepas dari faktor itu, tersebarnya naskahnaskah Nusantara juga disebabkan oleh "keteledoran" banyak pihak dalam menjaga, merawat dan mengkaji naskah yang ditulis oleh nenek moyang kita sendiri. Hal ini berimbas kepada kebutaan kita dalam mengenal sejarah literasi masa lalu. Padahal, dari manuskrip masa lalu, kita akan mengetahui perkembangan sejarah literasi masyarakat Nusantara mulai dari kepandaian mereka mengukir batubatu alam atau yang lazim dikenal dengan istilah 'batu bersurat' yang ditulis menggunakan huruf Pallawa dan memakai bahasa Sanskrit sampai kepada kelihaian mereka dalam menulis illuminasi di kertas-kertas Eropa.

Melihat sederet fakta tersebut, kita dapat menyatakan bahwa kajian yang dilakukan oleh para filolog dan komunitas pengkaji naskah 
kuno perlu mendapatkan apresiasi, karena di tengah kealfaan banyak orang tentang pentingnya menjaga dan meneliti kembali naskah-naskah kuno, mereka masih menyempatkan diri untuk menyelamatkan harta milik bangsa. Sejujurnya, kertas kerja ini adalah kelanjutan dari upaya tersebut. Tulisan ini dapat dianggap sebagai salah satu koyakan puzzle yang diharapkan mampu melengkapi koyakan yang lain, agar tercipta suatu pandangan utuh mengenai masa lalu masyarakat Indonesia, khususnya masyarakat Batu Cangku di Desa Sapit, Kecamatan Suela, Lombok Timur.

Dari sekian banyak rangkaian pembahasan dalam kertas kerja ini. Penulis meruntutnya dari aspek historisitas-transformatif-teologis sampai kepada peran dakwah Tuan Guru terhadap perkembangan budaya literasi. Dari sisi sejarah keberagamaan, masyarakat Sasak telah melewati beberapa anak tangga teologis: mulai dari AnimismeDinamisme, Hindu-Budha, BodaSasak, sampai kepada agama Islam yang dibawa oleh Sunan Prapen pada abad ke-16 M. ${ }^{3}$ Setelah kedatangan

3 Melihat sejarah yang tertulis diBabad Lombok, Pangeran Prapen merupakan Putra Sunan Giri, tetapi sejarah Jawa Timur menyebutkan Sunan Prapen adalah Cucu Sunan Giri. Lihat Pusat Penelitian Sejarah dan
Sunan Prapen, masyarakat Sasak di bagian timur Pulau Lombok dengan cepat menerima agama baru tersebut. Namun corak keberislaman mereka cenderung mistik atau yang lazim dikenal sebagai Islam Abangan. Koentjaraningrat menyebut religiusitas Islam Abangan di Jawa dengan Agama Jawi karena ajaranajaranyangterdapatdalamAgamaJawi telah menyatu dengan kepercayaan sebelumnya (Hindu-Budha) yang cenderung mistis. Dalam sejarah keberagamaan masyarakat Sasak, corak keberagamaan ini dinamakan Islam Waktu Telu. ${ }^{4}$

Dalam perjalanannya, masyarakat Islam Waktu Telu dinilai

Kebudayaan, Sejarah Daerah Nusa Tenggara Barat (Jakarta: Departemen Pendidikan dan Kebudayaan, 1978), 72. Lihat juga Asnawi, "Respon Kultural Masyarakat Sasak Terhadap Islam" dalam Jurnal Ulumuna, (Vol. 9, No. 1, Juni 2005), 4.

4 Masyarakat Bayan Lombok Utara menggunakan Istilah Islam "Wetu" Telu. Masyarakat Desa Karang Bayan Lombok Barat menyebutnya Islam "Teu" Telu. Sedangkan masyarakat Desa Sapit menyebutnya Islam "Waktu" Telu. Apapun sebutannya, namun maksudnya hampir sama: sebuah penyematan identitas terhadap masyarakat yang mempercayai Agama Islam namun masih percaya tentang adanya arwah leluhur yang mempengaruhi kehidupan mereka. Selain itu, istilah ini juga digunakan untuk menyebut sebagian masyarakat yang faham keagamaanya berbeda dengan masyarakat Muslim pada umumnya atau Islam Santri. 
telah "melenceng" dari ajaran Islam yang sesungguhnya. Maka pada abad ke-19, seusai melaksanakan ibadah haji, para Tuan Guru melakukan proses islamisasi jilid dua pada masyarakat yang masih memegang teguh corak Islam Waktu Telu. Tokohtokohnya adalah Tuan Guru Umar Buntimbe, Tuan Guru Mustafa, Tuan Guru Amin. Jamaludin menduga bahwa beberapa Tuan Guru, seperti Tuan Guru Haji Muhammad Zainuddin Abdul Madjid, Tuan Guru Mutawalli, Tuan Guru Safwan Hakim telah melakukan dakwah pemurnian Islam pertama kali pada abad ke-18. ${ }^{5}$ Berbeda dengan Jamaludin, beberapa peneliti sebelumnya, seperti Erni Budiwanti dan Abd. Syakur beranggapan bahwa dakwah Tuan Guru dimulai pada pertengahan abad ke-20 M.

5 Agak sulit memprediksi tahun berapa masyarakat Sasak pertama kali melakukan ibadah haji. Namun ada beberapa orang yang namanya diabadikan pada naskah-naskah Sasak yang ditulis di depan namanya haji, semisal Guru Bangkol, Haji Muhammad Ali. Selain itu, ada nama Tuan Guru Umar Buntimbe yang diperkirakan telah berhaji pada pertengahan abad ke-18, muridnya Tuan Guru Abdul Gafur Sumbekah, Tuan Guru Mustafa Sekarbela, Tuan Guru Amin Sesela. Lihat Jamaludin, Sejarah Sosial Islam di Lombok Tahun 17401935: Studi Kasus Terhadap Tuan Guru (Jakarta: Puslitbang Lektur dan Khazanah Keagamaan, 2011), 118-229.

\section{B. Transformasi Corak Keberagamaan Masyarakat} Sasak

Dalam bahasa Sangsekerta, agama diartikan peraturan. Makna ini bisa dipahami sebagai seperangkat aturan tentang moril dan materil kepada pemeluknya. Agama yang merupakan ajaran atau sistem yang mengatur tata keimanan (kepercayaan) dan peribadatan kepada Tuhan dan seperangkat kaidah yang mengatur sosial dan manusia dengan lingkungannya. Selain itu, agama diartikan sebagai sistem pengetahuan masyarakat yang didasari oleh sebuah proses kesadaran. Dengandemikian, pilihan terhadap agama sebenarnya adalah sebuah proses budaya yang penuh dengan ciri kemanusiaan. Latar belakang dan kepentingan yang terdapat dalam diri seseorang sangat berpengaruh pada cara beragama seseorang.Untuk berbagai situasi individu baik untuk memperoleh kehidupan yang tenang, maupun saat merasa teraniaya. Salah satu pakar sosiologi-hermeneutis, Joachim Wach menyatakan bahwa agama merupakan pengalaman tentang Yang Maha Kudus. Secara historis, agama lahir di dunia untuk keperluan manusiakarenaketidakmampuannya dalam mengatasi segala persoalan hidup yang secara tidak langsung 
mengantarkannya

kepada

kepercayaan terhadap sesuatu yang berada di luar dirinya yang dapat mengatasi persoalan di dalam kehidupan mereka.

Dalam sejarahnya, masyarakat Sasak pernah melalui beberapa kepercayaan:Animisme-Dinamisme, Hindu-Budha, Sasak-Boda, danIslam. Kepercayaan animisme merupakan kepercayaan masyarakat Sasak primitif. Dalam istilah antropologi, animisme merupakan kelompok atau aliran yang mempercayai kekuatan supranatural atau dengan dengan perkataan sederhana, mereka mempercayai semua benda di dunia ini mempunyai jiwa atau roh. Oleh karena itu, roh itu harus dijaga dan tidak boleh dipermainkan. Roh itu diterjemahkan sebagai nenek moyang mereka yang telah meninggal. Oleh karena itu, mereka berusaha untuk membangun hubungan harmonis dengan roh nenek moyang yang dipercaya masih "bergentayangan"walaupun jasadnya sudah tidak ada lagi. Mereka percaya bahwa roh nenek moyang mereka masih bisa dimintai pertolongan agar masyarakat terhindar dari musibah dan bencana. Dalam waktu tertentu, roh nenek moyang mereka juga dapat menjadi tempat "meminta restu" ketika akan melakukan sesuatu hal yang dianggap penting. Adapun bentuk kepercayaan animisme yang masih melekat pada masyarakat suku Sasak sampai saat ini adalah ketemuqyang merupakan bentuk pertemuan antara arwah nenek moyang dengan orang yang dirasukinya.

Disampingmenganut Animisme, masyarakat suku Sasak zaman dahulu juga menganut paham dinamisme, sebagai kepercayaan yang mengarah kepada pemujaan terhadap benda-benda, binatang dan lainnya yang memiliki kekuatan gaib. Benda atau binatang tersebut dipercaya oleh masyarakat suku Sasak dapat menjauhkan mereka dari gangguan makhluk halus yang jahat dan menghindarkan mereka dari malapetaka, selain itu benda atau binatang tersebut dipercaya mendatangkan kebahagiaan, banyak rizki, panjang umur, dan sebagainya. Karena masyarakat sasak pada waktu itu masih "awam" sehingga masyarakat Sasak banyak melakukan penyembahan pada benda-benda yang dianggap keramat, dengan melakukan berbagai ritual sebagai bentuk penghormatan pada benda yang dianggap memiliki kekuatan magis. Bentuk kepercayaan itu tercermin pada penghormatan pada sumur atau lingkoq, jika 
melewati sumur yang dianggap angker, biasanya masyarakat betabeq (permisi) terlebih dahulu.

Setelah dua kepercayaan tersebut, agama budhadiperkirakan telah ada di Pulau Lombok sekitar abad ke-8 atau ke-9 M. Agama Budha sebagaimana halnya agama-agama lain dipercaya mempunyai pengaruh yang cukup besar dalam kebudayaan masyarakat Sasak; baik dalam tata cara peribadatan, tata cara kehidupan mereka sehari-hari maupun adat istiadat mereka. Pendapat tentang kepercayaanmasyarakatSasakterkait Agama Budha ini, memang masih dalam perdebatan para ahli sejarah keagamaan masyarakat Sasak. Hal ini dikarenakan belum ada bukti yang menunjukkan tentang Agama Budhayang pernah dianut oleh masyarakat Sasak. Selain itu, tidak ada bukti fisik yang menunjukkan bahwa pada dahulu kala masyarakat Sasak pernah menganut agama ini. Dari beberapa agama yang telah disebutkan di atas, agama hindujuga termasuk agama yang dianut oleh masyarakat Sasak yang diperkirakan mulai masuk sekitar abad ke-11 M yang diperkenalkan oleh pendatang dari Bali. Agama Hindu sesungguhnya tidak banyak memberikanperubahanyangberarti, karena Ajaran Agama Hindu yang berpusat pada penyembahan roh nenek moyang dan kekuatan alam telah terlebih dahulu ada sebelum ajaran Agama Hindu masuk ke Lombok. Oleh karena itu, Agama Hindu di Lombok mudah diterima oleh masyarakat Sasakitu sendiri.

Sedangkan kepercayaanbodasasakadalah kepercayaan asli masyarakat Sasak. Meskipun ada kemiripan nama antara Boda dan Budha, akan tetapi kedua kepercayaan ini tidaklah sama, karena penganut kepercayaan Boda tidak mengakui Sidarta Gautama atau Sang Budha sebagai figur utama pemujanya maupun terhadap ajaran pencerahannya. Masyarakat Sasak yang menganut kepercayaan Boda disebut sebagai Sasak-Boda yang ditandai dengan pemahaman Animisme dan Panteisme;pemujaan dan penyembahan terhadap arwah leluhur dan berbagai dewa lokal lainnya yang merupakan fokus utama dari praktek keagamaan Boda-Sasak.

Adapun bentuk kepercayaan Boda-Sasak yang masih melekat pada masyarakat Sasak adalah penamaan terhadap Tuhan.Jika dalam Islam, Tuhan dikenal dengan nama Allah, maka masyarakat Sasak menyebutnya dengan sebutan Nenek. Selain itu, kata Lombok Mirah Sasak 
Adi juga disebutkan dalam Babad Negarakertagama yang ditulis oleh Mpu Prapanca pada zaman kerajaan Majapahit. Dari babad ini kita dapat mengidentifikasi tentang hubungan masyarakat Lombok dengan kerajaan Majapahit yang telah berlangsung lama, bahkan sebelum kerajaan-kerajaan lain melakukan ekspansi kekuasaan ke Lombok. Ekspansi kerajaan Majapahit ke Lombok pertama kali dipimpin oleh Mpu Nala sekitar tahun 1343 M dan ekspansi kedua dipimpin oleh Gajah Mada pada tahun $1353 \mathrm{M}$, sepuluh tahun setelah kedatangan $\mathrm{Mpu}$ Nala. Dalam manuskrip Bencingah dijelaskan bahwa keluarga kerajaan Majapahit melahirkan beberapa anak yang menjadi raja di Lombok. Seperti keturunan Mpu Nala yang melahirkan Deneq Mas Korebela dan Deneq Mas Laki Singia yang membangun kedatuan Bayan. ${ }^{6}$ Selain untuk memperluas daerah kekuasaan, kedatangan orang-orang Majapahit juga membawa berbagai tradisi, adat, budaya dan bahkan

6 Dalam BabadLombok dijelaskan bahwa kedatuan Bayan adalah kedatuan besar yang didirikan oleh putra Sri Baginda Majapahit ( ... hatmajane susunan Majapahit, hakarya negara luhung, nenggeh ning desa Bayan ...) Lihat Lalu Gde Suparman, Babad Lombok (Jakarta: Pusat Pembinaan dan Pengembangan Bahasa Departemen Pendidikan dan Kebudayaan, 1994), 110. kepercayaan. Agama Majapahit dikenal oleh masyarakat Sasak sebagai agama Boda. Argumentasi ini didasarkan pada berbagai gelar dan nama dewa-dewa Boda yang merupakan warisan dari MajapahitHindu.

Semenjak kedatangan agama Islamyang dibawa oleh Sunan Prapen atas perintah Sunan Giri dari Pulau Jawa, penganut ajaran Boda mulai terisolasi. Sunan Prapen datang dengan membawa misi mengislamkan masyarakat Sasak, sebagaimana yang tertulis dalam Babad Lombok.

"Hingsun niki saking Giri, Jawa. Kawulane Sunan Ratu Ningrat. Ngentining Rasul Jenenge, hingsung ningngutus dangu, henyelami hing sira sami; wong Lomboklan SumbawaNusa Bali Badung ..."

Saya ini dari Giri Jawa, rakyat dari Sunan Ratu Ningrat. Beliau menlanjutkan tugas Rasul dan (memerintahkan) saya untuk meng-Islam-kan kalian semua: orang Lombok, Sumbawa dan Bali Badung ...

Kedatangan Sunan Prapen disambut oleh Prabu Rangke Sari beserta patih, punggawa dan menteri di Menanga Baris. Di samping kedatangan Sunan Prapen, orang-orang Makassar 
juga datang dari Pulau Sumbawa pada abad ke-16 M dan berhasil menguasai kerajaan Selaparang, kerajaan Sasak asli. Kedatangan mereka memberikan pengaruh baru bagi corak keberagamaan masyarakat Sasak yang sebelumnya menganut kepercayaan BodaSasak. Banyak dari masyarakat yang mulai meninggalkan kepercayaan lama mereka dan beralih menuju kepercayaan baru yang dibawa dari Jawa dan Makassar. Dua daerah inilah yang membentuk corak keberagamaan masyarakat Sasak yang kemudian disebut dengan Islam Waktu Lima dan Islam Waktu Telu. Corak keberagamaan Islam Waktu Lima tidak jauh beda dengan corak keberagamaan masyarakat Muslim pada umumnya.

Sedangkan corak keberagamaan Islam Waktu Telu agak sedikit berbeda. Corak keberagamaan mereka mirip dengan masyarakat abangan di Jawa. Koentjaraningrat menyebut religiusitas abangan di Jawa dengan agama Jawi. Penyebutan ini mengarah kepada penyatuan antara agama Islam dan agama sebelumnya (Hindu-Budha) yang cenderung mistis. Pendapat lain menyatakan bahwa kemunculan ajaran Islam Waktu Telu lebih kepada pengaruh kerajaan Karang
Asem yang melakukan hinduisasi masyarakat Sasak, karena bukan hanya orang Jawa dan Makassar saja yang datang ke Lombok bagian timur. Kedatangan Karang Asem dari Bali di bagian barat juga turut memberikan warna tersendiri bagi perkembangan corak keberagamaan masyarakat Lombok. Terlebih setelah Karang Asem menguasai Lombok dari tahun 1678 sampai 1849. ${ }^{7}$

Terlepas dari perdebatan historisitas tersebut, sebelum tahun 1967 kita masih dapat menjumpai komunitas Islam Waktu Telu yang berdomisili di sekitaran lereng Gunung Rinjani: daerah Bayan, Sembalun dan Sapit. Namun setelah 1967, kita hanya akan menjumpai sebagian kecil dari penganut Islam Waktu Telu. Salah satu penyebabnya adalah gencarnya dakwah para Tuan Guru (kiyai) di komunitas yang dianggap "menyimpang" tersebut. Seperti Tuan Guru Muhammad Zainuddin Abdul Madjid pendiri Nahdaltul Wathan (NW) beserta para muridnya, Tuan Guru Mutawalli Jerowaru, Tuan Guru Mahsun

7 Alfons van der Kraan, "Selaparang Under Balinese and Dutch Rule: A History of Lombok 1870-1940" (Makalah yang dipresentasikan dalam Requirements of the Degree of Doctor of Philosophy in The Australian National University pada Agustus 1976), 6. 
Masbagik, Tuan Guru Zainuddin Pimpinan Marakit Taklimat, Tuan Guru Ibrahim Kediri, serta Tuan Guru yang lainnya. Walaupun dengan cara yang cukup beragam, namun inti dari dakwah mereka cenderung sama: mengembalikan mereka ke dalam ajaran Islam Waktu Lima sebagaimana yang dijalankan oleh masyarakat Muslim pada umumnya.

\section{Tuan Guru dan Perubahan Sosial-Keagamaan}

Hubungan Nusantara dengan Timur Tengah memang telah berlangsung sejak abad ke-17 M. Pada umumnya, hubungan itu bersifat keagamaan dan keilmuan, meskipun ada hubungan politik antara beberapa kerajaan MuslimNusantara, semisal dengan Dinasti Ustmaniyah. Bahkan saking banyaknya penduduk Nusantara di Hijaz, maka terbentuklah kampung Jawah yang terletak di Syamiyah, Syib Ali dan Al-Falaq. Pada aba ke17, kita mengenal nama Syaikh Yusuf Makassar yang berangkat ke Tanah Arab pada tahun 1670 dan kembali ke Indonesia pada tahun 1670. Setelah pulang ke Indonesia, ia bukan saja menyebarkan Tarekat Khalwatiyah saja, namun ia mempunyai peranan politik yang cukup penting sebagai penasehat Sultan Agung Tirtayasa di Banten. Realitas ini menunjukkan bahwa perjalanan ke tanah Arab bukan saja untuk mengerjakan ibadah Haji, namun mereka juga menetap di sana untuk menuntut ilmu. Sepulang mereka ke Tanah Air, mereka tidak hanya menjadi pemuka agama, namun mereka juga menjadi aktor-aktor politik.

Realitas di atas tidak jauh berbeda dengan realitas Tuan Guru di Lombok. Semenjak runtuhnya kerajaan-kerajaan Islam; Kerajaan Islam Selaparang, Kerajaan Pejanggik di Lombok Tengah dan kerajaan-kerajaan kecil lainnya pada abad ke-18, masyarakat IslamSasak lebih memilih untuk menjadi tokoh agama di tengah masyarakat, mereka menyekolahkan anak-anak mereka ke Timur Tengah untuk memperdalam ilmu agama Islam. Maka lahirlah tokoh-tokoh seperti Tuan Guru Umar Buntimbe, Tuan Guru Mustafa Sekarbela, Tuan Guru Amin Sesela dan bahkan ada juga Tuan Guru yang menjadi ulama besar di Makkah yaitu Tuan Guru Umar Kelayu. Mereka inilah para Tuan Guru yang memelopori dakwah pemurnian akidah, karena setelah kepulangan mereka ke Pulau Lombok untuk mengubah kepercayaan masyarakat Islam-Sasak 
yang saat itu masih terpengaruh kepercayaan sebelumnya.

Sedangkan pada ke-19 dan awal abad ke-20, beberapa nama seperti Tuan Guru Ali Batu, Tuan Guru Muhammad Sidiq Karang Kelok, Tuan Guru Muhammad Amin Ampenan yang kemudian dilajutkan oleh murid-muridnya seperti Tuan Guru Abdul Hamid al-Makki, Tuan Guru Abdul Mu'in Pagutan, Tuan Guru Arsyad Cakranegara, Tuan Guru Muhammad Zainuddin Abdul Madjid pendiri Nahdlatul Wathan (NW) dan murid-muridnya, Tuan Guru Mutawalli Jerowaru, Tuan Guru Safwan Hakim, Tuan Guru Mahsun Masbagik dan Tuan Guru Hazmi dari Marakit Taklimat Mamben. Mereka mulai mendatangi masyarakat dan berdakwah dengan berbagai macam metode dakwah.

Jika dirunut ke belakang, kharismatik Tuan Guru berawal dari cerita tentang kehebatan dan kelebihan yang dimilikinya, sehingga masyarakat Sasak sangat menaruh hormat pada setiap Tuan Guru, bahkan sampai wafatnya, makamnya masih sering diziarahi. Seperti yang dinyatakan masyarakat Danger tentang Tuan Guru Mahsun Masbagik,

"Tuan Guru Mahsun memiliki adalah guru kami, dia banyak mengajarkan tentang bagaimana beragama dengan baik dan benar. Selain itu, Tuan Guru Mahsun juga memiliki kelebihan-kelebihan yang tidak dimiliki manusia pada umumnya. Setiap malam Jum'at, ia pergi ke sawah dekat rumahnya untuk mengadu ilmu dengan siapa saja yang ingin mencoba ilmu kanuragannya."8

Hal lain yang mengangkat popularitas Tuan Guruadalah politik. Dulu, Tuan Guru menjadi tempat bersandar dan referensi kehidupan masyarakat, termasuk dalam hal politik. Tuan Guru dianggap mampu menafsirkan perpolitikan nasional karena keterbatasan yang dimiliki oleh pengikutnya. Masyarakat Sasak menjunjungtinggiinterpretasipolitik Tuan Guru di samping kekecewaan mereka terhadap pemerintah yang otoriter juga terhadap karisma Tuan Guru yang dianggap melebihi diri mereka sendiri. Sehingga banyak masyarakat yang menyandarkan segala urusannya kepada titah Tuan Guru. Selain itu, Tuan Guru juga tidak hanya mengisi majelis-majelis taklim, mereka juga mendirikan sekolah atau madrasah tempat menuntut ilmu, seperti Tuan Guru Muhammad Zainuddin Abdul Madjid yang mendirikan Pondok

Hasil Wawancara Riki Febri

.Ramdhani pada 28 Juni 2018 
Pesantren Al-Mujahidin yang kemudianmenjadiDarunNahdlatain NW Pancor dan Tuan Guru Mahsun yang mendirikan Pondok Pesantren Al-Ijtihad. Di tempat itu, sebagian masyarakat menitipkan anaknya untuk belajar ilmu-ilmu Agama Islam. Hal ini yang menyebabkan banyaknya orang tua santri yang hormat kepada para pimpinan Pondok Pesantren.

Selain memiliki pesantren, secara struktural, Tuan Guru di Lombok juga memiliki organisasi keagamaan seperti Nahdlatul Wathan (NW) dan Nahdlatul Ulama (NU). Anggota dari dua organisasi besar tersebut memiliki banyak massa dan secara otomatis pengikutnya akan sangat menghormati pemimpin organisasi. Dengan adanya dua organisasi itu pula, banyak dari kader-kader utamanya diperintahkan untuk berdakwah ke kalangan masyarakat Islam Waktu Telu. Seperti Tuan Guru Juani Mukhtar yang diutus untuk berdakwah ke Narmada pada tahun 1952, dan menetap di Tanak Beak sampai wafatnya pada tahun 2008. Wilayah Narmada pada waktu itu masih menganut Islam Waktu Telu. Secara perlahan, Tuan Guru Juaini yang merupakan kader Nahdlatul Wathan mampu mengubah corak keberagamaan masyarakat setempat. Sedangkan dari kalangan Nahdlatul Ulama, Tuan Guru Mahsun Masbagik yang merupakan murid dari Tuan Guru Saleh Hambali Bengkel melanjutkan misi dakwahnya ke daerah Batu Cangku dan Batu Pandang. Dakwahnya terbilang cukup sukses, karena pada tahun 1965, masyarakat setempat sudah tidak lagi memperaktikkan ibadah ala Islam Waktu Telu.

Deretan informasi di atas memberikan gambaran tentang karismatik Tuan Guru mampu merubah corak keberagamaan masyarakat. Mulai dari kekeramatan yang melekat pada masing-masing individu, pandangan politik, sampai kepada pendirian organisasi. Semua itu adalah wadah untuk melakukan proses evolusi dari corak keberagamaan yang sinkretis menuju corak keberagamaan yang murni. Untuk menjalankan ritual keberagamaan secara murni, maka masyarakat Batu Cangku memiliki buku pedoman pelaksanaan ibadah keseharian mereka. Manuskrip tersebut dinamai naskah perukunan oleh masyarakat setempat.

\section{Naskah Perukunan: Internalitas dan Eksternalitas Teks}

Dari data sejarah, kita mengetahui bahwa tradisi tulis- 
menulis masyarakat Sasak dimulai semenjak hubungan mereka dengan masyarakat Bali, Jawa dan Bugis. Kontak sosial tersebut dapat dilihat dari beberapa naskah yang ditulis menggunakan bahasa dan aksara daerah itu. Semisal Naskah Bugis yang ditulis di atas kertas dengan menggunakan aksara dan bahasa Bugis. Kondisi naskah yang jumlah halamannya 38 itu terbilang cukup baik. Naskah ini dapat dijumpai di Penjor, Desa Gondang, Kecamatan Gangga, Lombok Utara. Sedangkan naskah-naskah berbahasa Bali juga banyak ditemukan di Lombok bagian barat. Diduga kuat naskahnaskah tersebut ada setelah kerajaan Bali berhasil menaklukkan kerajaan Islam di Lombok sekitar abad ke$17 \mathrm{M}$. Bahkan ada beberapa sumber yang menyatakan tentang interaksi masyarakat Sasak dengan Bali telah berlangsung lama, bahkan sebelum kerajaan Bali melakukan ekspansi kekuasaan.

Sedangkan pengaruh Jawa memang paling dominan pada naskah-naskah di Lombok, bahkan bahasa Jawa dianggap sebagai bahasa sastra di Lombok. Pengaruh ini dimulai pada abad ke-9 dan 10 M semenjak masyarakat Sasak melakukan kontak dengan masyarakat Jawa. Pengaruh Jawa dapat dilihat dari penggunaan bahasa Jawa Kuno dan Sansekerta yang cukup banyak digunakan dalam beberapa naskah. Selain itu, kita juga menemukan nama-nama daerah yang meminjam nama daerah di Jawa, semisal Kediri di Lombok Barat, Gerisak dan Wanasaba di Lombok Timur. Pengaruh Jawa juga dapat dilihat di Babad Selaparang, Babad Lombok dan Babad Sapit. Kedua babad di atas telah diterjemahkan dan dialih aksara ke dalam aksara Latin dengan menggunakan bahasa Indonesia yang dilakukan oleh Lalu Gde Suparman pada tahun 1994 dan diterbitkan oleh Pusat Pembinaan dan Pengembangan Bahasa Departemen Pendidikan dan Kebudayaan. Sedangkan Babad Sapit masih belum mendapatkan penelitian lanjutan.

Selain pengaruh kebudayaan tiga daerah di atas, pengaruh Islam juga sangat terlihat di beberapa naskah, semisal naskah Nur Muhammad, Nabi Ibrahim, Yazid, Malaikat Jibril, Nabi Aparas, Puspakrama dan beberapa naskah mushaf AlQur'an. Naskah Al-Qur'an banyak ditemukan di Lombok. Banyaknya naskah Al-Qur'an berawal dari tradisi penyalinan naskah yang dilakukan oleh masyarakat Sasak kala itu, karena penyalinan mushaf 
Al-Qur'an adalah salah satu syarat mendapatkan gelar tokoh agama. Pada tahun 2016, Ali Akbar menulis katalog yang dipamerkan pada momen Musabaqah Tilawatil Qur'an (MTQ) tingkat Nasional ke-26 yang diselanggarakan di Mataram, Nusa Tenggara Barat. Ia mencantumkan 20 mushaf Al-Qur'an. 15 diantaranya disimpan oleh Museum Negeri NTB di Mataram, 5 naskah lainnya berasal dari koleksi Masjid, pribadi dan koleksi Art Gallerry of South Australia di Adelaide, Australia. Beberapa mushaf tersebut dianggap mampu mewakili mushaf-mushaf yang tidak diketahui jumlahnya secara pasti, terlebih yang tersebar di tengah masyarakat (Akbar 2016: 4).

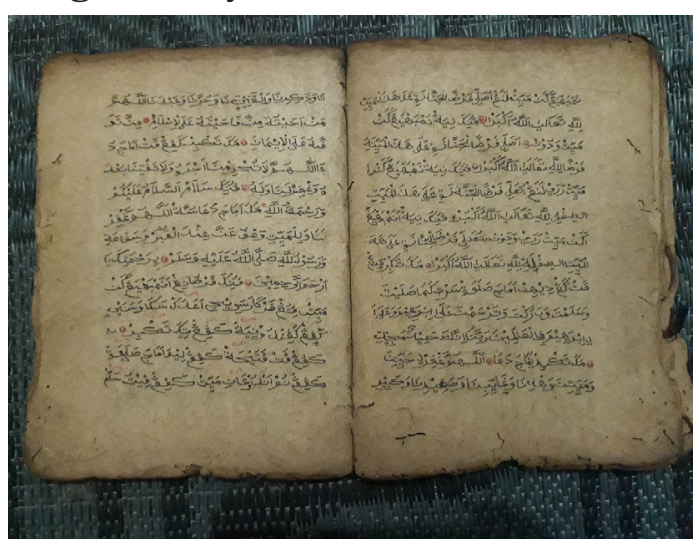

Gambar 1. Naskah Perukunan Batu Cangku

Naskah Islam lain yang disimpan oleh masyarakat adalah naskah Perukunan. Naskah ini disimpan oleh Subur Jaya yang dapat ditemukan di Dusun Batu Cangku,
Desa Sapit, Kecamatan Suela, Lombok Timur. Kondisi naskah masih dalam kondisis terawat, karena menurut penuturan penyimpannya, naskah selalu dibersihkan setiap hari Kamis malam. Namun untuk pembacaan naskah sendiri telah jarang dilakukan, mengingat banyaknya naskah cetak yang lebih komprehensif menjelaskan tentang tata cara mengerjakan ibadah dalam Agama Islam. ${ }^{9}$ Naskah dibersihkan menggunakan kain husus yang telah dipersiapkan sebelumnya. Hal ini tentu kurang baik untuk perawatan naskah kuno, karena reservasi naskah mempunyai teknik-teknik khusus dan alat yang khusus pula.

Naskah Perukunan Islam Waktu Lima dulunya digunakan sebagai buku pedoman sederhana dalam melakukan peribadatan seharihari masyarakat Islam Waktu Lima, karena dalam sejarah, dulunya masyarakat Batu Cangku menganut Islam Waktu Telu sebagai corak keberagamaan mereka. Hal ini dapat dibuktikan dengan berbagai situs yang dianggap sebagai situs Waktu Telu, seperti Makam Batu Pandang dan Makam Tanah Gadang. Kedua tempat itu, masih diziarahi hingga saat ini, Makam Batu Pandang

Hasil Wawancara Subur Jaya 9 .pada 26 Juni 2018 
diziarahi ketika akan menanam padi, sedangkan Makam Tanah Gadang diziarahi ketika masyarakat mempunyai hajat dan niat tertentu.

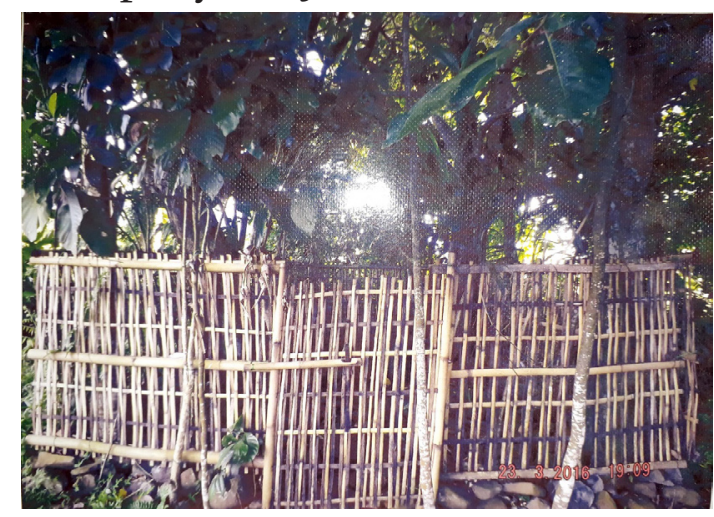

Gambar 2. Situs Batu Pandang

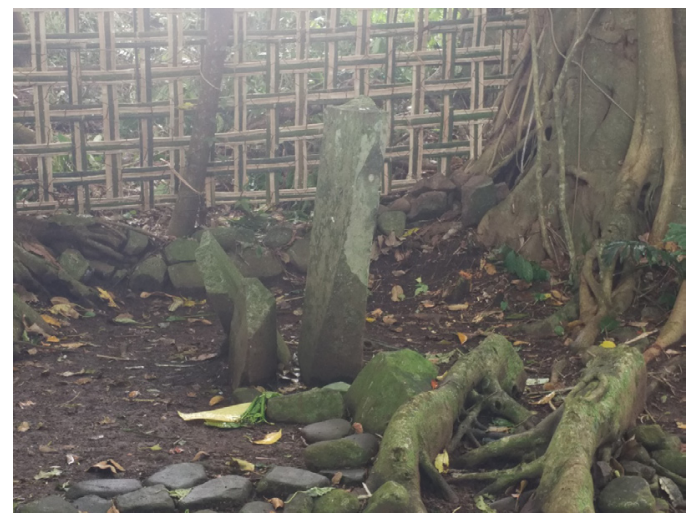

Gambar 3. Makam Tanah Gadang

Setelah tahun 1965 , masyarakat Batu Cangku kedatangan seorang Da'i dari Masbagik yang bernama Tuan Guru Mahsun. Secara berkala, Tuan Guru Mahsun dengan pengajian-pengajian yang dilakukan mampu mengubah corak keberagamaan masyarakat Batu Cangku dari Islam Waktu Telu menuju Islam Waktu Lima. Sampai saat ini, tokoh tersebut sangat dihargai dan dihormati di tempat tersebut, sehingga banyak orang tua yang memilih menyekolahkan anaknya di Pondok Pesantren Al-Ijtihad di Danger, Masbagik. ${ }^{10}$ Padahal, jarak antara Dusun Batu Cangku dengan Danger terbilang cukup jauh; 25 KM dan dapat ditempuh dalam kurun waktu kurang lebih 40 Menit menggunakan motor.

Selain itu, pada waktu menganut Islam Waktu Telu, masyarakat tidak mengerjakan salat kecuali beberapa waktu saja, seperti salat Jumat, salat Idulfitri dan salat Iduladha. Dalam melakukan ibadah puasa pun demikian, mereka tidak berpatokan pada tata cara melakukan ibadah puasa pada masyarakat Muslim umumnya. Mereka menyantap sahur ketika matahari sudah tinggi dan berbuka ketika akan matahari masih bersinar terang. Sedangkan ibadahibadah lainnya diserahkan kepada kiyai dan sebagai gantinya, mereka akan menyerahkan sebagian kecil dari hasil panen tanaman mereka. ${ }^{11}$

Setelah kedatangan Tuan Guru Mahsun tersebut, masyarakat sedikit demi sedikit mulai berubah dalam hal kepercayaan. Mereka

\footnotetext{
Hasil Wawancara Amaq Ulpi 1. .(Mangku Adat) pada tanggal 29 Juni 2018 Hasil Wawancara Papuk Dika 11 .pada 28 Juni 2018
} 
mulai melakukan salat lima waktu dan puasa selama sebulan penuh di Bulan Ramadhan. Naskah Perukunan merupakan naskah yang dipercaya ditulis oleh salah seorang murid pertama Tuan Guru Mahsun, namun adapula yang berpendapat bahwa naskah tersebut telah ada sebelum Tuan Guru Mahsun datang ke Batu Cangku. Pendapat itu didasarkan kepada realitas masyarakat yang saat itu belum bisa membaca dan menulis, karena hanya sebagian kecil masyarakat yang menempuh pendidikan. Belum lagi jika melihat realitas tentang bangunan sekolah yang saat itu belum ada; masyarakat yang ingin menempuh pendidikan formal harus pergi jauh ke Selong, Ibukota Kabupaten Lombok Timur. Perdebatan tentang historisitas naskah ini wajar terjadi, karena naskah Perukunan Islam Waktu Lima tidak memiliki kolofon naskah, sehingga menyulitkan untuk menganalisis kapan dan siapa penulis naskah tersebut.

Secara observasional, naskah tersebutmenggunakankertasdaluang (kertas kulit kayu). Jenis kertas ini lumrah digunakan pada naskah Jawa, hal ini yang membedakan antara naskah-naskah kesultanan Bima dan Sumbawa yang menggunakan kertas Eropa karena mendapat pengaruh kuat dari Sulawesi Selatan. Dari aspek ekonomi, harga kertas Eropa memang relatif lebih mahal dari daluang (kertas lokal). Oleh karena itu, jenis daluang biasa digunakan di kalangan pesantren dan masyarakat biasa (jajar karang) pada umumnya. Sedangkan kertas Eropa biasa digunakan oleh lembagalembaga pemerintahan, istana, dan kalangan bangsawan (menak) yang mempunyai cukup uang untuk membeli kertas. Di sisi lain, jenis kertas juga berpengaruh pola desain mushaf dengan tujuan-tujuan tertentu, semisal pihak keraton yang seringkali mempertimbangkan penggunaan kertas Eropa karena akan dihias sedimikian rupa untuk menggambarkan kemewahan dan kemegahan kerajaannya. Sedangkan bahan daluang mempunyai tekstur serat yang berbeda sehingga tidak dimungkinkan untuk melakukan hiasan. Oleh karena itu, jarang ditemukan tulisan yang berbahan duluang dengan hiasan yang indah. ${ }^{12}$ Begitu pula dengan Naskah Pusaka ini, tidak terdapat illuminasi yang indah di dalamnya.

12 Lebih lanjut lihat Annabel Teh Gallop, “The Art of The Qur'an in Java: Some Preliminary Observations" dalam Makalah yang disampaikan pada Islamic Area Studies Converence di Universitas Malaya pada 2008. 
Naskah ini juga ditulis dengan menggunakan bahasa Sasak dan bahasa Jawa dengan menggunakan aksara Arab-Melayu. Kosa kata bahasa Sasak yang sering dijumpai di naskah ini adalah lamun (jika atau apabila) dan amaca (membaca). Seperti dalam pembahasan salat, dalam naskah itu tertulis, "lamun Zuhur ..., lamun Șubuḥ ..., lamun Aṣar ..., lamun Magrib ..., lamun Isya" sedangkan kata amaca terdapat ketika pembahasan tentang ucapanucapan ketika melakukan salat, seperti "Maka Amaca Qunut Ing Dalem Șubuh." Sedangkan bahasa Jawa dapat dilihat dari penggunaan kata ing (di) seperti dalam potongan kalimat di atas. Dari naskah ini, kita dapat melihat akulturasi antara bahasa Jawa dan bahasa Sasak dalam satu naskah.

Naskah ini juga ditulis dengan menggunakan rasm imlā'i, namun masih terdapat beberapa kesalahan dalam konteks penulisannya. Seperti ketika menuliskan ayat kursi; dalam naskah dituliskan

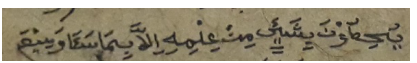

sedangkan seharusnya ayat tersebut dituliskan dengan و لايحيطونبشي

selain itu, ada juga kesalahan dalam harakat seperti

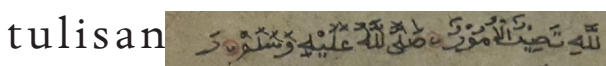

صلباللهعليهو سلم yang seharusnya ditulis dengan menggunakan harakat "pada huruf $l \bar{a} m$ dan masih banyak lagi kesalahan penulis (corrupt) yang lainnya.

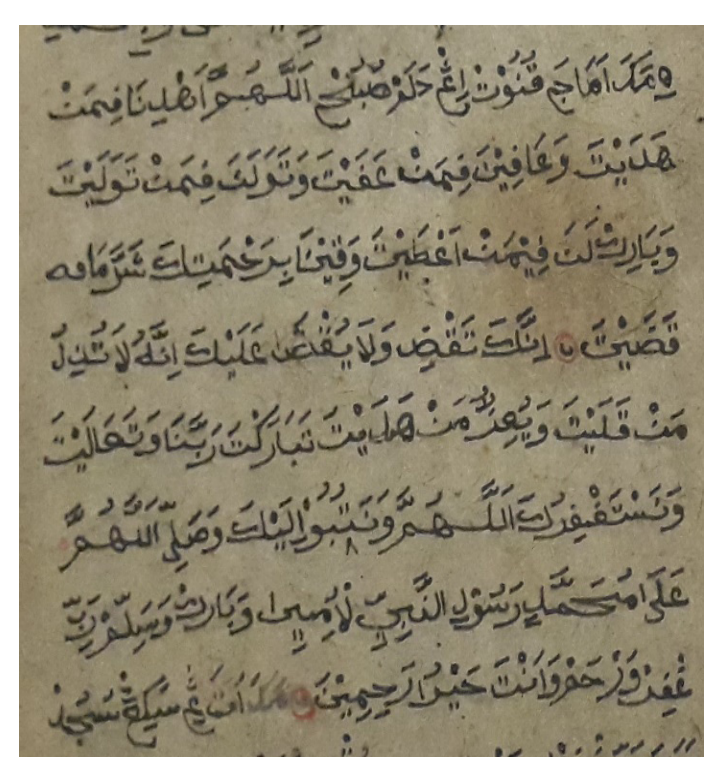

Oleh karena itu, jika naskah ini dibaca saat ini pasti akan sangat kelihatan bahwa naskah ditulis bukan oleh kalangan agamawan, semisal Tuan Guru, namun naskah ditulis oleh seorang yang masih belum mengerti kaidah-kaidah penulisan huruf Arab. Hal ini pula yang menguatkan asumsi bahwa naskah ditulis oleh murid pertama dari Tuan Guru Mahsun yang belum terlalu lama mengenal Islam dan belum mengenal seutuhnya kaidah penulisan Arab.

Jika dilihat secara substansi, naskah yang ditulis menggunakan tintahitamitumembicarakan tentang 
tata cara melaksanakan ibadah sehari-hari masyarakat Muslim pada umumnya (Islam Waktu Lima). Pada awal naskah dituliskan pujian-pujian kepada Allah lalu disambung dengan barisan doa-doa yang di dalamnya dituliskan kalimat Syahadāt. Setelah itu, pembahasannya langsung mengarah kepada lafaz-lafaz azan yang harus dikumandangkan lima kali sehari semalam dan dilanjutkan dengan doa sebelum membaca AlQur'an. Lafaz niat salat menjadi pembahasan selanjutnya dan begitu pula dengan lafaz-lafaz yanglain yang harus dibaca ketika salat, seperti doa iftitāḥ, qunut dan lain sebagainya.

Jika ditelusuri secara mendalam, penjelasan singkat tentang tata cara melaksanakan syariat Islam menggunakan mazhab Syāfi'i. Seperti membaca doa qunut ketika melaksanakan salat Subuh. Dalam naskah Perukunan tersebut dijelaskan bahwa "maka amaca qunut ing dalam subuh" tidak ada penjelasan lanjutan karena memang fungsi naskah ini hanya untuk mengajarkan tata cara salat dan tidak untuk dipelajari secara perbandingan mazhab. Padahal dalam mazhab fikih, ulama berbeda pendapat tentang qunut. ${ }^{13}$ Realitas masa lampau masyarakat tersebut, tidak jauh berbeda dengan realitas saat ini; sama-sama menggunakan bermazhab Syāfi'i. Adapun beberapa hal yang mendorong masyarakat menganut aliran mazhab itu adalah (1) ada organisasi terbesar di Pulau Lombok bernama Nahdlatul Wathan (NW) yang didirkan oleh TG. KH. Muhammad Zainuddin Abdul Madjid. Dalam bidang fikih, organisasi ini menganut mazhab Syāfi'i sesuai dengan AD-ART organisasi tersebut. (2)

13 Imām Syāfi'i menyatakan bahwa tidak ada qunut pada salat lima waktu selain salat Subuh. Kecuali jika terjadi bencana, maka boleh qunut pada semua salat jika imam menyukainya. Lihat Abi 'Abd Allāh Muḥammad ibn Idrīs al-Syāfi'i, al-Umm, terj. Ismail Ya'qub(Jakarta: CV. Faizan, 1984), 205. Mazhab Hanafi dan Mazhab Hambali menyatakan bahwa qunut itu sunnah pada saat salat Witir, sedangkan pada saat salat Subuh, mereka tidak menganggapnya sunnah. Lihat Imām Syams al-Dīn, Mugni al-Muhtaj (Syiria: Dār al-Faiha', t.th), 151-152. Sedangkan menurut Imām Mālik, qunut adalah ibadah sunnah pada salat Subuh dan lebih utama dikerjaka sebelum ruku'. Meskipun dilakukan setelahnya juga dibolehkan. Lihat Imām Ibn Qudamā', al-Syarh al-Kabìr (Lebanon: Dār al'Arabi, t.th), 248. Mazhab ini terbentuk karena adanya perbedaan pandangan mengenai dalil primer dalam Islam. Perbedaan diskursus para ulama pada tataran uṣul dan furū' merupakan penyebab utamanya. Lihat Taqiy al-Dīn alNabhani, al-Syakhsiyah al-Islāmiya (Beirut: Dār al-Ummah, 1994), 386. 
organisasi terbesar di Lombok juga Nahdlatul Ulama (NU). Walaupun mengakui empat mazhab, namun dalam praktiknya, fikih NU lebih bersumber pada mazhab Syāfi'i, sehingga pola pikir dan prilaku masyarakat NU dibentuk dibentuk oleh pemahaman ala mazhab Syāfi'i.

(3) Majelis-majelis taklim di Masjid ataupun di pesantren-pesantren mengajarkan buku-buku fikih ala Syāfi'i, seperti Fath al-Qarīb, Fath al-Mu'in, Perukunan Melayu, Sabil alMuhtadīn, Kifāyah al-Akhyār, Ibānah al-Ahkam dan kitab-kitab fikih yang lain.

Dari realitas tersebut, kita melihat bahwa Tuan Guru memiliki peran sentral dalam perkembangan budaya literasi di tengah masyarakat. Dengan memerintahkan muridmuridnya untuk menulis sebuah manuskrip, maka peran dakwah Tuan Guru bukan hanya untuk menularkan ideologi keagamaan dalam konteks sosial-kebudayaan, namun juga menularkan semangat literasi dan memerangi buta huruf. Dari sini, kita juga dapat melihat metode dakwah yang tidak hanya mengandalkan ceramah keagamaan namun para Tuan Guru juga mengandalkan metode literasi karena melihat masyarakatnya yang belum bisa menulis.

\section{E. Penutup}

Manuskrip

Perukunan

merupakan manuskrip yang digunakan masyarakat Muslim pertama di Batu Cangku sebagai buku panduan dalam melaksanakan ibadah sehari-hari. Dari manuskrip sederhana itu, kita dapat mengetahui mazhab pertama yang mereka anut. Berdasarkan observasi terhadap naskah tersebut, kita dapat mengetahui bahwa tata cara ibadah yang terdapat dalam manuskrip tersebut lebih dekat kepada tata cara ibadah ala mazhab Syāfi'i. Jadi, dari awal transformasi keberagamaan masyarakat Batu Cangku dari Islam Waktu Telu menuju Islam Waktu Lima, mereka telah diperkenalkan tentang tata cara ibadah menurut mazhab Syāfi'i, maka tidak mengherankan jika sampai saat ini, mereka masih memegang teguh ajaran tersebut. Di lain sisi, Tuan Guru Mahsun yang datang pertama kali dakwah ke tempat tersebut juga merupakan anggota Nahdlatul Ulama (NU) yang menganut mazhab Syāfỉ. Begitu pula dari buku-buku yang dipelajari anak-anak Batu Cangku yang keluar menuntut ilmu di Pondok Pesantren, mereka banyak diajarkan kitab-kitab yang berafiliasi ke mazhab Syāfi'i. 


\section{Daftar Pustaka}

Agung, Ide Anak Agung Gde, Bali Pada Abad XIX; Perjuangan Rakyat dan Raja-Raja Menentang Kolonialisme Belanda 1808-1908, (Yogyakarta: Gajah Mada University Press,1989)

Faizal Amin, "Preservasi Naskah Klasik" dalam Jurnal Khatulistiwa, (Vol. 1. No. 1. Maret 2011)

Oman Fathurrahman, "Proyek Digitalisasi Naskah Aceh dan Dampaknya bagi Pengembangan Perpustakaan Digital Naskah Nusantara" dalam Makalahyang Disampaikan dalam Seminar Internasional Kebijakan dan Strategi Pelestarian Naskah Kuno Aceh di Museum Negeri Aceh pada tanggal 22-23 Desember 2009.

Nindya Noegraha, "Tradisi Penulisan Naskah Jawa" pada Seminar Antarbangsa Manuskrip Melayu, di (Kuala Lumpur, 3-4 Oktober, 1995)

Pusat Penelitian Sejarah dan Kebudayaan, Sejarah Daerah Nusa Tenggara Barat (Jakarta: Departemen Pendidikan dan Kebudayaan, 1978)
Asnawi, "Respon Kultural Masyarakat Sasak Terhadap Islam" dalam Jurnal Ulumuna, (Vol. 9. No. 1. Juni 2005)

Jamaludin, Sejarah Sosial Islam di Lombok Tahun 1740-1935: Studi Kasus Terhadap Tuan Guru,(Jakarta: Puslitbang Lektur dan Khazanah Keagamaan, 2011)

Lalu Gde Suparman, Babad Lombok (Jakarta: Pusat Pembinaan dan Pengembangan Bahasa Departemen Pendidikan dan Kebudayaan, 1994)

Alfons van der Kraan, "Selaparang Under Balinese and Dutch Rule: A History of Lombok 1870-1940" Makalah yang dipresentasikan dalam Requirements of the Degree of Doctor of Philosophy in The Australian National University pada Agustus 1976

Hasil Wawancara Riki Febri Ramdhani pada 28 Juni 2018

Hasil Wawancara Subur Jaya pada 26 Juni 2018

Hasil Wawancara Amaq Ulpi (Mangku Adat) pada tanggal 29 Juni 2018

Hasil Wawancara Papuk Dika pada 28 Juni 2018 
Annabel Teh Gallop, "The Art of The Qur'an in Java: Some Preliminary Observations" dalam Makalah yang disampaikan pada Islamic Area Studies Converencedi(Universitas Malaya pada 2008)

Abi 'Abd Allāh Muhammad ibn Idrīs al-Syāfi'i, al-Umm, Terj. Ismail
Ya'qub,(Jakarta: CV. Faizan, 1984)

Imām Syams al-Dīn, Mugni al-Muhtaj (Syiria: Dār al-Faiḥa’, t.th).

Imām Ibn Qudamā', al-Syarh al-Kabìr (Lebanon: Dār al-Arabi, t.th)

Taqiy al-Dīn al-Nabḥani, alSyakhsiyah al-Islāmiya,(Beirut: Dār al-Ummah, 1994) 